Pregledni rad

https://doi.org/10.31784/zvr.9.1.20

Datum primitka rada: 14. 12. 2020.

Datum prihvaćanja rada: 19. 1. 2021.

\title{
ZNAČAJ RAZVOJNIH BANAKA ZA FINANCIRANJE UBLAŽAVANJA I ADAPTACIJE KLIMATSKIH PROMJENA
}

\section{Draženka Draženović Kostelac}

Mr. sc., voditeljica područnog ureda, Hrvatska banka za obnovu i razvitak, Strossmayerov trg 9, 10000

Zagreb; e-mail: ddrazenovic@hbor.hr

\section{Slađana Benković}

Dr. sc., redovita profesorica, Sveučilište u Beogradu, Fakultet organizacionih nauka, Jove llića 154, 11000 Beograd, Srbija; e-mail: sladjana.benkovic@fon.bg.ac.rs

\section{Bojana Olgić Draženović}

Dr. sc., izvanredna profesorica, Ekonomski fakultet, Sveučilište u Rijeci, I. Filipovića 4, 51000 Rijeka, Hrvatska; e-mail: bojana.olgic.drazenovic@efri.hr

\section{SAŽETAK}

Klimatske promjene i globalne negativne posljedice zahtijevaju mjere za prilagodbu na održiviji model rasta i razvoja ekonomija. Stoga se kao prioritet nameće ublažavanje štetnih posljedica i poticanje održivog i klimatski otpornog gospodarstva. Jednu od ključnih uloga u procesu transformacije gospodarstava na nisko-ugljičnu budućnost imaju razvojne banke. Cilj rada je istražiti ulogu razvojnih banaka u klimatskim financijama kroz pregled literature i analizu podataka o klimatskim financijama država članica Odbora za pomoć u razvoju unutar Organizacije za ekonomsku suradnju i razvoj u razdoblju od 2012. do 2018. godine. Korišten je metodološki pristup analize postojećih teorijskih ishodišta i empirijska analiza dostupnih sekundarnih podataka. Očekivani doprinos ovog rada je u povećanju vidljivosti značaja razvojnih banaka kao kanala distribucije klimatskih financija koje su bile značajan dionik za transmisiju klimatskih financija od razvijenih ka slabije razvijenim državama.

Ključne riječi: klimatske financije, razvojne banke, održivi razvoj

\section{UVOD}

Zadnjih godina globalni održivi razvoj postao je vodeće načelo brojnih globalnih i nacionalnih dionika, kao proces ili program restrukturiranja ekonomskih, društvenih i tehničkih odnosa kako bi se zaštitila priroda i čovjekova okolina (Krstinić Nižić, Zubović, 2016). Istraživanja pokazuju da najveći utjecaj na klimatske promjene ima ispuštanje ugljikova dioksida u atmosferu, koji zbog 
svojih svojstava pojačava učinak staklenika. U sljedeća dva desetljeća očekuje se porast temperature za oko $0,2^{\circ} \mathrm{C}$ u svakom desetogodišnjem razdoblju, ako emisije stakleničkih plinova nastave rasti trenutačnim tempom (Šverko Grdić, Špoljarić, 2018). Ciljevi održivog razvoja' definirali su nove razvojne ciljeve i tendencije, a Pariški sporazum ${ }^{2}$ je ojačao ambicije globalne zajednice u borbi protiv štetnih klimatskih promjena i razarajućih globalnih posljedica. Klimatske promjene i s njima povezani globalni humanitarni i ekološki problemi okupljali su nacije pod pokroviteljstvom Ujedinjenih naroda kako bi promovirali mjere prilagodbe i ublažavanja klimatskih promjena koje se dugo nazivaju 〈održivim razvojem `. Postignut je međunarodni konsenzus o razvoju politika i tijeku financijskih sredstava usmjerenih ka postizanju nižih emisija stakleničkih plinova i razvoja gospodarstva otpornog na klimatske promjene. Premda mnoge nerazvijene zemlje, pogotovo države niskog dohotka, nisu trenutno veliki izvor emisija, obvezale su se na pokretanje i provođenje tranzicije prema klimatski kompatibilnoj budućnosti (OECD, 2018). Europska Unija povećava razinu korištenja obnovljivih izvora energije u gospodarstvu. Prema zadnje dostupnim podatcima, u 2018. godini 17,9 \% ukupne potrošnje energije se ostvaruje iz obnovljivih izvora. Ipak, ovakvim vrijednostima EU se još uvijek nalazi ispod propisanoga cilja od $20 \%$.

Kako bi se postiglo globalno smanjenje emisije stakleničkih plinova, posebno je potrebno ograničiti emisiju u sektorima poljoprivrede, šumarstva, korištenju zemlje, industriji, transportu i zgradama, a pogotovo u sektoru energije koji najviše doprinosi emisiji stakleničkih plinova i odgovoran je za otprilike 35 \% ukupne emisije (IPCC, 2014). Nerazvijene države imat će snažnu potrebu za financiranjem velikih infrastrukturnih projekata kako bi se postigli ciljevi održivog razvoja, smanjila ranjivost i povećala otpornost prema štetnim klimatskim promjenama. Do sada te zemlje nisu uspjele doći do potrebnih razina međunarodnih javnih klimatskih financija (UNEP, 2016). U financiranju ovakvih vrsta projekata ključnu ulogu imat će razvojne banke, a pogotovo multilateralne razvojne banke koje su i danas ključni dionici u globalnim klimatskim financijama i u razvojnim financijama općenito. Multilateralne razvojne banke su financijske institucije u javnom vlasništvu sa specifičnim razvojnim ili političkim mandatom i ključne su u adresiranju novih izazova vezano za klimatske promjene.

Cilj rada je istražiti ulogu i važnost razvojnih banaka kao kanala za distribuciju klimatskih financija, kao i geografsku distribuciju odobrenih pomoći i programa za ublažavanje i suzbijanje klimatskih promjena. Osim detaljnog pregleda prethodnih istraživanja, izvršena je empirijska analiza podataka Organizacije za ekonomsku suradnju i razvoj u razdoblju od 2012. do 2018. godine. Radom je dokazana hipoteza kako su razvojne banke raznoliko i neujednačeno korištene kao kanal distribucije klimatskih financija od strane država članica Odbora za razvojnu pomoć OECD-a.

Rad se sastoji od šest cjelina. Nakon uvodnog dijela prikazan je pregled literature o klimatskim financijama, a zatim se daje osvrt na izvore sredstava i na geografski aspekt klimatskih financija. U sljedećem dijelu analizira se uloga razvojnih banaka u ublažavanju i prilagodbi klimatskim

1 Novi program održivog razvoja do 2030. godine(Transforming our World:2030 Agenda for Sustainable Development) usvojen je na Općoj skupštini Ujedinjenih naroda 25. rujna 2015. godine.

2 Pariški sporazum o klimatskim promjenama je potpisan na Okvirnoj konvenciji Ujedinjenih naroda o promjeni klime (UNFCCC) u Parizu 2015. godine s glavnim ciljem ograničavanja globalnog zatopljenja na temperature „znatno ispod" $2{ }^{\circ} \mathrm{C}$. 
promjenama te završno rezultati predmetne analize. Posljednji dio rezerviran je za zaključna razmatranja.

\section{PREGLED LITERATURE O KLIMATSKIM FINANCIJAMA I ULOZI RAZVOJNIH BANAKA}

Literatura koja obrađuje tematiku klimatskih financija usmjerena je na nekoliko glavnih područja: učinkovitost klimatskih financija i uspješnost ostvarivanja zadanih ciljeva, analiza rizika povezanih s klimatskim financijama, privlačenje privatnih izvora sredstava za financiranje projekata povezanih s klimom, usporedba metoda i definicija za procjenu mobiliziranih klimatskih financija, nekonzistentnost definiranja klimatskih financija, pregled volumena i distribucije klimatskih financijskih tijekova, izazovi zemalja u razvoju s kojima se suočavaju prilikom tranzicije ka niskougljičnoj i klimatski otpornoj ekonomiji, utjecaj razvojnih financijskih institucija na klimatske promjene te razvoj novih radnih mjesta kao posljedica korištenja klimatskih financija. Većina autora istražuje problematiku učinkovitosti klimatskih financija, uspješnost u ostvarivanju ciljeva kao i adekvatnost korištenja sredstava. Buchner et al. (2011) pronalaze da većina posrednika u sustavu klimatskih financija nije razvila dovoljno specijalizirane procedure za procjenu učinkovitosti klimatskih financija. Financiranje projekata povezanih s klimom uključuje mnoge rizike koje je potrebno primjereno procijeniti i pronaći načine ublažavanja i upravljanja predmetnim rizicima. Kennedy i Corfee-Morlot (2012) istražuju i rangiraju najznačajnije rizike u financiranju niskougljičnih i klimatski otpornih projekata. Zaključuju da je politički ili rizik države najveći rizik za ovu vrstu projekata. Štoviše, potencijal za financiranje nisko-ugljičnih i klimatski otpornih projekata u zemljama niskog dohotka nije u potpunosti iskorišten zbog oskudnih osnovnih bankarskih usluga, slabog kapaciteta upravljanja rizicima i ograničene dostupnosti dugoročnih izvora financiranja.

Financiranje klimatskih namjena dostupno je iz javnih, ali i iz privatnih izvora. Javna financijska sredstva se usmjeravaju putem raznih institucija, razvojnih banaka, ministarstava, agencija te mogu biti bilateralni ili multilateralni prema načinu grupiranja i usmjeravanja sredstava. Odobravaju se u obliku darovnica, koncesijskih kredita ili garancija. Privatni izvori klimatskih financija najvećim dijelom odnose se na subjekte koji razvijaju projekte (engl. project developers) i korporacije (UNFCCC, 2015), komercijalne banke, institucionalne investitore i infrastrukturne fondove. Privatni sektor predstavlja $75 \%$ globalnih tijekova klimatskih financija i esencijalan je za povećanje volumena klimatskih financija u okolnostima ograničenih javnih resursa (Buchner et al., 2012).

Tematiku privlačenja privatnih izvora financiranja ublažavanja i prilagođavanja klimatskim promjenama proučavali su: Brown et al. (2011), Agrawala et al. (2011), Whitley i Ellis (2012), Ockenden et al. (2012), Stadelmann i Michaelowa (2013), Caruso i Ellis (2013), Srivastava i Venugopal (2014), Würtenberger i Wils (2014), Caruso i Jachnik (2014), Stumhofer et al. (2015), Brown et al. (2015), Jachnik et al. (2015), Abeille et al. (2015), Pauw et al. (2015), McNicoll et al. (2017) te Broccolini et al. (2020). Snažan interes za proučavanje uloge i potrebe privlačenja privatnih financijskih sredstava za potrebe klimatskih financija može se opravdati činjenicom kako se bez privatnih izvora sredstava ne mogu postići ciljevi i obveze preuzete Pariškim sporazumom i Ciljevima održivog razvoja. Brown et al. (2011) proučavaju tematiku privlačenja privatnih izvora financija vezano za klimu. Caruso i Ellis (2013) uspoređivali su metode za procjenu mobiliziranih 
klimatskih financija i utvrdili da je potrebno povećati usporedivost procjena i izvješća mobiliziranih klimatskih financija između država. Navedenu nekonzistentnosti potvrđuju i Ellis i Moarif (2015) i u svom radu zaključuju da izvješća država nisu usporediva, kompletna niti konzistentna, a to onemogućuje precizne i adekvatne procjene i analize. Izvještavanje o mobiliziranim privatnim financijama će postati obvezno po Pariškom sporazumu što je ključni izazov za razvijene države. McNicoll et al. (2017) analiziraju javno mobilizirane privatne financije za klimatske aktivnosti u Južnoj Africi između 2010. i 2015. godine. Rezultati istraživanja ukazuju da domaći javni akteri odrađuju najveću mobilizacijsku ulogu kroz pružanje potpore ciljanim politikama, a u manjoj mjeri sufinanciranjem na razini projekata. Širi prikaz javnih financijskih tijekova za razvoj infrastrukture u nerazvijenim zemljama od strane bilateralnih i multilateralnih razvojnih partnera utvrdili su Miyamoto i Chiofalo (2016). U radu je prikazan sveobuhvatan pregled volumena i distribucije financijskih tijekova, uključivši one kanalizirane operacijama privatnog sektora i one koje su mobilizirane od privatnog sektora kroz garancije, sindicirane kredite i kolektivne investicijske projekte. Tirpak et al. (2014) prikazuju devet tehničkih, političkih i izazova vezanih za kapacitet s kojima se suočavaju zemlje u razvoju, a odnose se na nekonzistentne definicije i kriterije za definiranje klimatskih financija, kao i nekonzistentne markere, indikatore i kodove za karakteriziranje financijskih podataka (po sektorima ili aktivnostima), nedovoljne institucionalne aranžmane koji uključuju nejasne uloge i odgovornosti različitih ministarstava, nedovoljni tehnički procesi i sustavi za identifikaciju i evidenciju troškova klimatskih financija, nedostatak informacija o klimatskim financijama koje pružaju nevladini dionici, nedostatak kapaciteta za nadgledanje različith financijskih instrumenata, nedostatak podataka o privatnim financijama, nedostatak transparentnosti i predvidivosti.

Istraživanja koja procjenjuju utjecaj razvojnih financijskih institucija na klimatske promjene na makro razini su rijetke. Postoji samo jedna studija te vrste koju je proveo Te Velde 2011. godine. Provedena je regresijska analiza efekata razvojnih financijskih institucija (EIB, EBRD, IFC i CDC) na energetsku učinkovitost izraženu kao korištenje energije po 1.000 \$ BDP-a. Rezultati pokazuju da IFC i EBRD vode ka većoj energetskoj učinkovitosti, dok takvih efekata nema za EIB i CDC na tom uzorku. Te Velde (2011) razvija općenitu metodologiju za procjenu agregatnog utjecaja razvojnih financijskih institucija na investicije i sposobnosti ovih institucija u poboljšanju energetske učinkovitosti. Dokazi upućuju da ove institucije povećavaju ukupnu investicijsku aktivnost i popravljaju energetsku učinkovitost u zemljama primateljicama. Zaključak je da jedan postotni bod povećanja investicija razvojnih financijskih institucija kao postotni dio od BDP-a vodi do 0,8 $\%$ promjene u omjeru investicija prema BDP-u. Jouanjean i Te Velde (2013) procjenjuju stvaranje direktnih i indirektnih poslova od strane raznih razvojnih financijskih institucija uz korištenje kvantitativnih metoda analize. Zaključeno je kako su međunarodne razvojne institucije omogućile razvoj 2,6 milijuna poslova u nerazvijenim zemljama u 2007. godini. Rezultati istraživanja ukazuju da je radna produktivnost povećana najmanje $3 \%$ u dvadeset i jednoj državi niskog i srednjeg dohotka. Eschalier et al. (2015) u svom radu predstavljaju mogućnosti i izazove povezivanja tranzicije na nisko-ugljični razvoj s ciljevima razvojnog financiranja. Zaključeno je da razvojne financijske institucije mogu imati utjecaj na ublažavanje i adaptaciju klimatskim promjenama i na okolišnu održivost kroz tri kanala: a) podupiranjem nisko-ugljičnih, klimatski otpornih razvojnih modela moguće je ohrabriti i pokrenuti smjer javnih i privatnih investicija prema nisko-ugljičnim 
projektima, ali i ubrzati promjene u regulatornom okviru. Ove institucije mogu igrati krucijalnu ulogu u omogućavanju pristupa kapitalu i rješavanju tržišnih neuspjeha, pomoći u razvoju nacionalnih, regionalnih i lokalnih razvojnih strategija i regulatornih okvira koji su koherentni sa nisko-ugljičnom tranzicijom, ostvarivanju suradnje s lokalnim bankama i financijskim institucijama u uspostavi zelenih kreditnih linija; b) stavljanjem adaptacije u fokus ove institucije mogu doprinijeti da se osigura da klimatski rizici budu sistematično uzeti u obzir u investicijskom odlučivanju i da se poduzmu adekvatne adaptacijske mjere; c) integriranjem financijskog rizika i prikladnim vrednovanjem investicija ove institucije mogu odigrati ulogu u poboljšanju integracije klimatskih i ugljičnih (regulatornih) rizika u investicijsko odlučivanje i osigurati poduzimanje adekvatnih adaptacijskih mjera.

Nastanak, funkcije i pozicioniranje razvojnih banaka u financijskim sustavima te područja koja financiraju istražena je u velikom broju radova. De Luna-Martínez i Vicente (2012) naglašavaju važnost uloge razvojnih banaka kao instrumenta vlada u promicanju ekonomskog razvoja. Pružanjem dugoročnih izvora financiranja, kreditnih garancija i ostalih usluga u infrastrukturi, kućanstvima i poljoprivrednom sektoru. Posebno je istaknuta uloga razvojnih banaka za vrijeme globalnih financijskih kriza i dokazuje kako su iste preuzele kontra cikličku ulogu kroz povećanje svoje kreditne aktivnosti u vrijeme kad su privatne banke smanjile financiranje privatnom sektoru. Thorne i du Toit (2009) definiraju razvojne banke kao oblik intervencije vlade u financijski sustav koji pokušava riješiti tržišne nedostatke u pružanju financijskih sredstava ili općenito ostvariti društveno-ekonomske ciljeve kao što je smanjenje siromaštva ili omogućavanje dostupnosti vlasničkog kapitala. Razvojne financije su definirane kao omogućavanje financiranja onim tržǐnnim segmentima (projektima, sektorima ili dijelovima stanovništva) koji nisu dovoljno servisirani financijskim sustavom.

Matić i Serdarušić (2009) naglašavaju ulogu razvojnih banaka u financiranju infrastrukturnih projekata i projekata posebne važnosti za pojedinu državu u okolnostima nezainteresiranosti komercijalnog bankarskog sektora.

\section{IZVORI SREDSTAVA I GEOGRAFSKI ASPEKT KLIMATSKIH FINANCIJA}

Klimatske financije su ključni koncept mobiliziranja kapitala u ublažavanju štetnih posljedica klimatskih promjena. Financiranje klimatskih pitanja uključuje službenu razvojnu pomoć (engl. Official Development Assistance-ODA), ostale službene tijekove sredstava (engl. Other Official Flows$O O F)$, privatne darovnice i privatna mobilizirana sredstva.

Klimatske financije se dijele na dvije glavne skupine:

- financiranje tzv. adaptacije ili prilagodbe - aktivnosti usmjerene na smanjenje ranjivosti i osjetljivosti ljudskih i prirodnih sustava na štetne posljedice klimatskih promjena te na izgradnju otpornosti i smanjenje izloženosti;

- financiranje tzv. mitigacija ili ublažavanja klimatskih promjena - odnose se na smanjenje emisije iz fosilnih goriva, poticanje alternativa u smislu korištenja obnovljivih izvora energije, sprječavanje uništavanja šuma i sl. 


\section{Draženović Kostelac, S. Benković, B. Olgić Draženović: Značaj razvojnih banaka za financiranje... Zbornik Veleučilišta u Rijeci, Vol. 9 (2021), No. 1, pp. 329-343}

Većina financijskih sredstava usmjerava se u financiranje mitigacije. Prema podacima OECD-a (2018) za razdoblje od 2012. do 2018. godine, iz perspektive država donatora klimatskih financija, 69 \% klimatskih financija ili 65 milijardi američkih dolara odnosilo se na projekte ublažavanja štetnih posljedica klimatskih promjena, a samo $31 \%$ ili 30 milijardi USD na prilagodbu klimatskim promjenama. Vremenski obuhvat podataka uključuje razdoblje nakon globalne financijske krize 2007. / 2008. kada su financijska tržišta zabilježila povijesno niske cijene kapitala te pogodovala iniciranju i implementaciji novih projekata i strategija razvojnog bankarstva. Culpeper (2012) posebno naglašava važnost razvojnih banaka u zemljama srednjeg i nižeg dohotka.

Klimatske financije analizirane su na dva načina. Prva je perspektiva primatelja, koja obuhvaća sva sredstva primljena za klimatske namjene od strane bilateralnih i multilateralnih donatora. Druga perspektiva odnosi se na onu od strane donatora, a uključuje bilateralne kontribucije i sredstva koja su dodijeljena multilateralnim institucijama koje ih implementiraju u državama primateljicama. Sukladno navedenom, klimatske financije se usmjeravaju državama primateljicama na dva načina. Jedan od načina je bilateralni tijek klimatskih financija kojim država donator direktno usmjerava sredstva primatelju. Drugi način je korištenje međunarodnih organizacija kao kanala distribucije sredstava. Međunarodne organizacije primaju multilateralne kontribucije i usmjeravaju ih državama primateljicama. Navedeno je prikazano shemom 1.

Shema 1. Tijekovi klimatskih financija

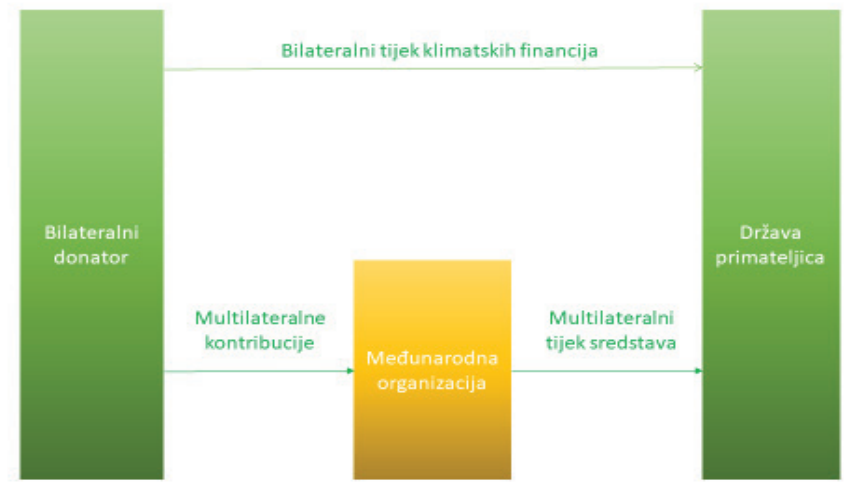

Izvor: OECD, 2018

Grafikonom 1 prikazano je koliko su države donatori koristile razvojne banke kao kanal distribucije za klimatske financije. Najveći udio razvojnih banaka i fondova u ukupnim klimatskim financijama imaju Grčka 63 \% i Slovačka 53 \%, a najmanje Japan 7 \%. Analizirajući podatke može se zaključiti da države koje nemaju tradiciju ulaganja u klimatske financije i nemaju razvijene vlastite kanale distribucije, koriste razvojne banke kao siguran način pravilne raspodjele sredstava, dok države koje ulažu značajna sredstva i imaju tradiciju financiranja projekata povezanih s klimom, s vremenom su razvile vlastite kanale distribucije, kroz razvojne agencije, ministarstva ili druge nacionalne institucije. 
Grafikon 1. Udjeli klimatskih financija razvojnih banaka u ukupnim klimatskim financijama iz perspektive država primateljica u razdoblju od 2012. - 2018. godine (\%)

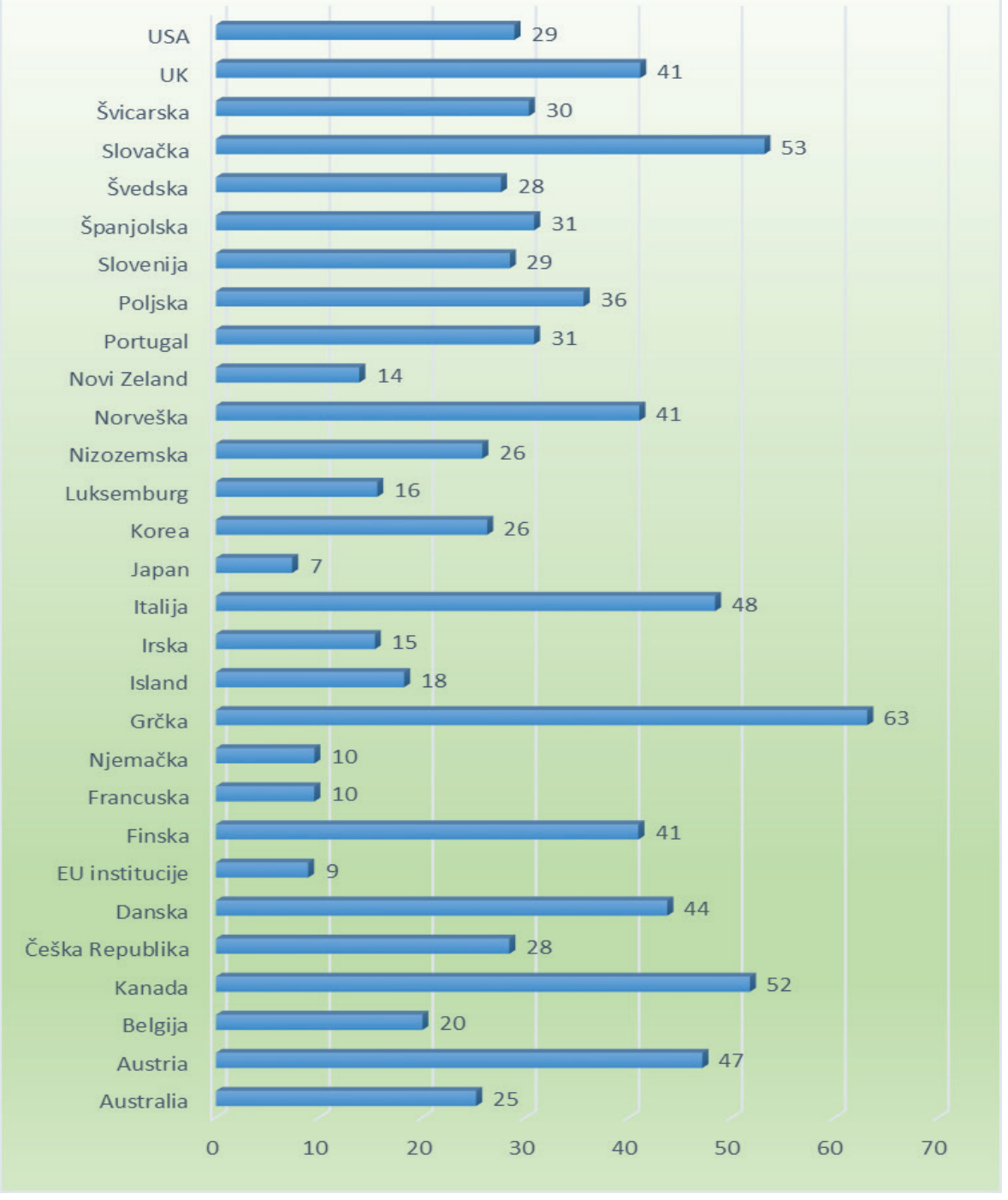

Izvor: izradili autori prema OECD (2019)

Prema integriranim podacima bilateralnih i multilateralnih klimatskih financija od 2012. do 2018. godine iz perspektive država primateljica, odobreno je 230,2 mlrd USD za klimatske financije. Pri tome je dio financiranja usmjeren putem razvojnih banaka i multilateralnih razvojnih fondova iznosio 37,9 mlrd USD ili 16,4 \% od ukupnih odobrenih financijskih sredstava. Korištenje razvojnih banaka kao kanala distribucije za klimatske financije je raznoliko. Skandinavske države u prosjeku koriste razvojne banke kao kanal distribucije s udjelom od 38 \%. Kanada i Sjedinjene Američke Države usporedive po geografskom položaju i razvijenosti, raznoliko koriste razvojne banke kao 


\section{Draženović Kostelac, S. Benković, B. Olgić Draženović: Značaj razvojnih banaka za financiranje...}

Zbornik Veleučilišta u Rijeci, Vol. 9 (2021), No. 1, pp. 329-343

kanal distribucije. Evidentno je kako geografski položaj, pripadnost regiji ili gospodarska razvijenost države ne utječu na korištenje razvojnih banaka kao kanala distribucije. Važnost pojedinih razvojnih banaka i multilateralnih razvojnih fondova iz perspektive država primateljica financijskih sredstava za klimatske namjene prikazan je grafikonom 2.

Grafikon 2. Udjeli razvojnih banaka i multilateralnih razvojnih fondova u ukupnim klimatskim financijama od 2012. - 2018. godine - perspektiva država primateljica

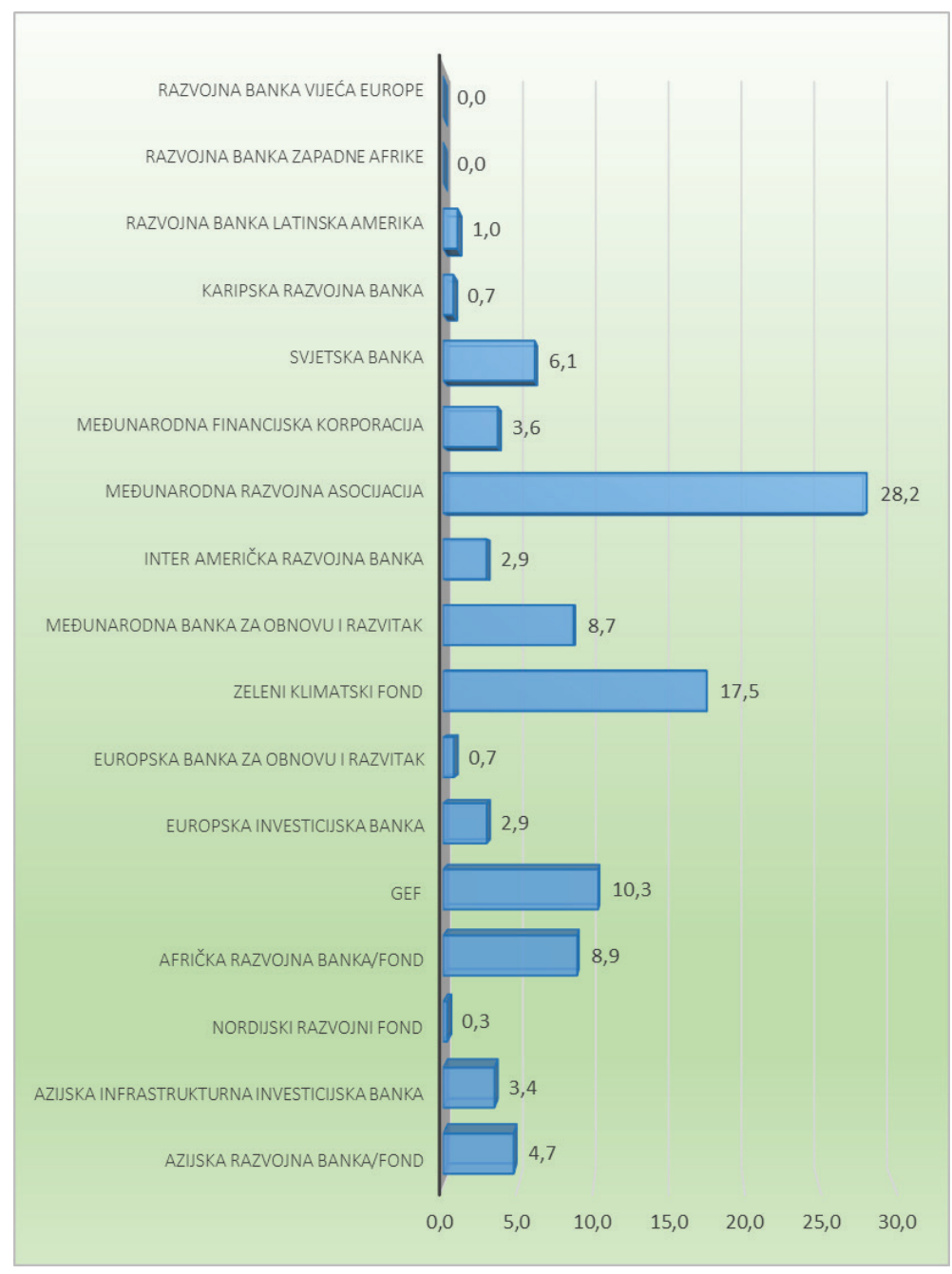

Izvor: izradili autori prema OECD (2019)

Dominacija Međunarodne razvojne asocijacije može se objasniti pripadnošću iste grupaciji Svjetske banke koja ima najveći udio u klimatskim financijama od multilateralnih banaka. Zeleni klimatski fond (eng. Green Climate Fund - GCF) osnovan je 2010. godine unutar Okvirne konvencije Ujedinjenih naroda o promjeni klime. Vidljivo je da postaje ključni financijski mehanizam za provedbu Pariškog sporazuma i ograničenje rasta globalne temperature. Geografska raspodjela 
klimatskih financija istražena je temeljem podataka istog promatranog perioda, a zaključci analize prikazani su grafikonom 3. Velik udio klimatskih financija čiji primatelji nisu specificirani ukazuje na nedostatak podataka za sveobuhvatniju analizu.

Grafikon 3. Geografska raspodjela klimatskih financija od 2012. do 2018. godine - perspektiva država primateljica

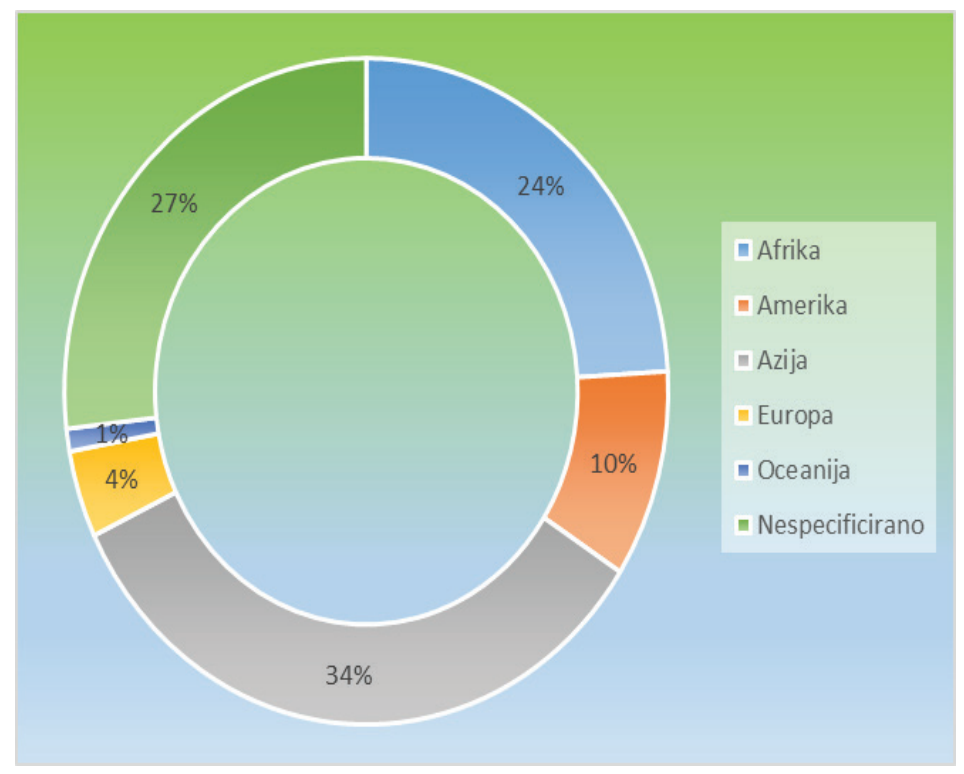

Izvor: izradili autori prema OECD (2019)

Analizom podataka o ukupnim iznosima klimatskih financija u promatranom razdoblju grafikonom 4 prikazani su udjeli pojedinih multilateralnih razvojnih banaka u istima. Dominacija Svjetske banke u klimatskim financijama je izrazita i sve ostale multilateralne banke imaju daleko manji opseg u klimatskim financijama. Jedan od razloga dominacije može se pronaći u činjenici kako je ista osnovana 1944. godine kao prva multilateralna razvojna banka i ima dugogodišnju tradiciju razvojnog bankarstva. 
Grafikon 4. Udjeli razvojnih banaka u ukupnim klimatskim financijama od 2012. do 2018. godine - perspektiva država donatora (u \%)

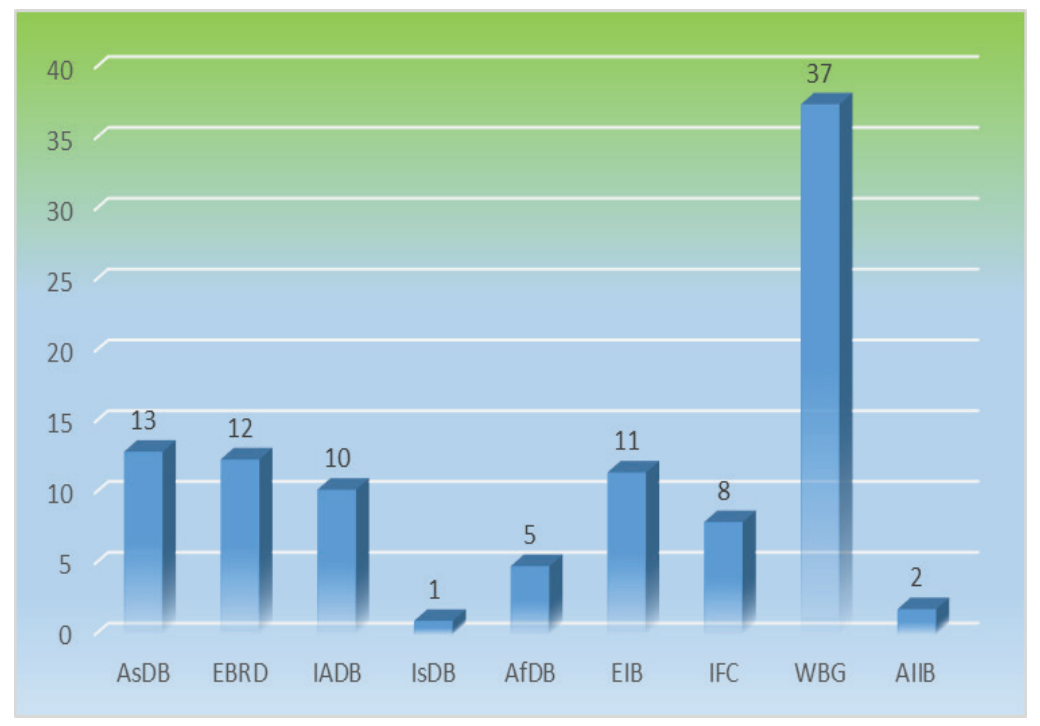

Izvor: izradili autori prema OECD (2019)

\section{ANALIZA I REZULTATI ANALIZE ULOGE RAZVOJNIH BANAKA U UBLAŽAVANJU I PRILAGODBI KLIMATSKIM PROMJENAMA}

Unutar stalno promjenjive strukture razvojnih financija, nacionalne razvojne banke, a pogotovo one iz nerazvijenih ekonomija, imaju veću i potencijalno transformacijsku ulogu u povećanju financija za nisku emisiju stakleničkih plinova i infrastrukturu otpornu na klimatske promjene u domaćem kontekstu. One mogu adresirati barijere za klimatske investicije specifične za pojedinu državu zbog svoje bliskosti tržištu i odnosu sa lokalnim javnim i privatnim dionicima. Nacionalne razvojne banke mogu biti začetnici održivog i odgovornog financiranja te pružati primjer ostalim nacionalnim financijskim institucijama odnosno imati učinak oponašanja i grupiranja. Utjecaj razvojnih financijskih institucija na klimatske promjene i okolišnu održivost izvršen je većinom u obliku procjene specifičnih projekata i inicijativa kroz studije slučajeva.

Razvojne banke izvještavaju pozitivne utjecaje na zaposlenost, na prihode javne uprave, na doseg kupaca i u nekim slučajevima okolišni, socijalni i upravljački ishod i razvojne utjecaje privatnog sektora, uz ograničenje dosega uslijed subjektivne ocjene i nedostatnih podataka kako bi precizno utvrdili efekti i rezultati. Dokazana je i pozitivna veza između investicija navedenih financijskih institucija i ekonomskog rasta. Massa et al. (2016) donose sveobuhvatan pregled literature o makroekonomskim efektima razvojnih financijskih institucija te zaključuju da iste imaju ključnu ulogu u pokretanju investicija i korištenju obnovljivih izvora energije u zemljama u razvoju. Pronađen je pozitivan i značajan utjecaj investicija razvojnih financijskih institucija na ekonomski rast i radnu produktivnost, koji potvrđuje transformacijski potencijal intervencija ovakve vrste. 
Nacionalne, regionalne, bilateralne ili multilateralne razvojne banke su financijeri infrastrukture, a ova uloga se još može ojačati usmjeravanjem investicija u infrastrukturu koja je klimatski otporna i niske emisije. Njihova dodana vrijednost je trostruka: a) koncesijsko i nekoncesijsko financiranje novih projekata koji uključuju nisku emisiju te infrastrukturu otpornu na klimatske promjene u zemljama u razvoju; b) razvojne banke mogu privući komercijalne investicije za projekte kroz poboljšavanje povrata investicija obzirom na rizik kroz alate i pristupe ublažavanja rizika;c) razvojne banke mobiliziraju investicije direktno kroz potporu vladama u reformiranju investicijskih politika, uklanjanju prepreka investicijama i stimuliranju stvaranja tržišta kako bi se povećala klimatska akcija (OECD, 2018).

Ipak, razvojne banke ograničene su u svojem djelovanju jer blagotvoran učinak na klimatska pitanja zahtijeva djelovanje i sinergiju više dionika. Njihove aktivnosti ovise i pod utjecajem su vlasnika udjela u kapitalu razvojnih banaka, te je značajan i utjecaj na alokaciju sredstava od strane vlada klijenata, tj. država primateljica klimatskih financija. Vlade vlasnika udjela u razvojnim bankama utječu na rad bilateralnih i multilateralnih razvojnih banaka kroz pružanje kapitala i revidiranje politika i projekata. Dok aranžmani upravljanja nacionalnim razvojnim bankama i bilateralnim bankama mogu varirati, mnogi od njih su sastavni dio vladinog sustava te njihovi mandati i aktivnosti direktno ovise o signalima politike. Kontekst države, ali i regionalni kontekst imaju snažan utjecaj na ambicioznost razvojnih banaka u jačanju financiranja klimatskih pitanja i mobilizaciji komercijalnih investitora.

Nedostatak projekata spremnih za financiranje u nerazvijenim zemljama, rizici tečaja i valutni rizici, ali i međunarodno regulatorno okruženje vezano za financijsku stabilnost (Basel III regulativa) mogu umanjiti i spriječiti napore da se mobilizira komercijalni kapital za infrastrukturu niske emisije kao što su obnovljivi izvori energije (OECD, 2018; Ang et al., 2017). Štoviše, nužno je da portfelj multilateralnih razvojnih banaka bude u skladu s Pariškim ugovorom odnosno da uključuje investicije koje aktivno podupiru ili ne podcjenjuju postavljene temperaturne ciljeve (Germanwatch i New Climate Institute, 2018). Jedan od problema učinkovitosti razvojnih banaka je ovisnost o političkim utjecajima. Vrlo često politički mandati ograničeni su na četiri godine, dok se orijentiranost razvojnih banaka na rješavanje problematike klimatskih promjena mora graditi dugoročnije, ali istovremeno i sustavno, promišljeno, ciljano i neometano. U globalnom smislu potrebno je poboljšati koordinaciju klimatskih inicijativa, putem razvojnih banaka i raznih multilateralnih fondova,-kako bi se izbjegla kontraproduktivna kompeticija i preklapanje aktivnosti.

\section{ZAKLJUČAK}

Posljednjih godina razvojne banke su predvodnice i potpora u ostvarivanju nisko-ugljične ekonomije te u stvaranju gospodarstva otpornog na klimatske promjene. Multilateralne razvojne banke su po svojoj snazi, kapacitetu i mogućnostima financiranja jedan od najjačih dionika u klimatskom financiranju. Osim osiguravanja financijskih sredstava po uvjetima znatno povoljnijim od tržišnih, pružaju i pomoć u obliku tehničke pomoći, darovnica za specijalne namjene, pomoći u promjeni regulativa, pravila i u provođenju reformi. 


\section{Draženović Kostelac, S. Benković, B. Olgić Draženović: Značaj razvojnih banaka za financiranje... Zbornik Veleučilišta u Rijeci, Vol. 9 (2021), No. 1, pp. 329-343}

Obzirom na značajna financijska sredstva koja će biti potrebna razvijenim i nerazvijenim državama, evidentno je kako se ta sredstva neće moći osigurati samo iz javnih izvora, već će biti potrebna privatna sredstva. Logika i način rezoniranja privatnih investitora je strogo tržišna, tj. traženje većih povrata na uloženi kapital, ako se preuzimaju veći rizici, a investicije povezane $s$ klimom nose $\mathrm{i}$ veće rizike zbog nepoznanica financijske, tehničke i tehnološke prirode. $U$ tom smislu uloga razvojnih banaka bit će još značajnija, jer one mogu pokriti rizike odobravanjem garancija odnosno biti poluga koja će omogućiti privatnom sektoru veći angažman i veću prisutnost u klimatskim financijama. Razvojne banke su prirodni kanal distribucije klimatskih financija obzirom na njihovu bliskost tržištu, kapacitete, znanje i sposobnost učinkovite alokacije sredstava. Razvojne banke i multilateralne razvojne fondove kao kanal distribucije klimatskih financija najviše koriste Grčka, Slovačka, Kanada, Italija, Austrija, Danska, Finska i Norveška. Najmanje se koriste u Japanu, institucijama Europske Unije, Njemačkoj i Francuskoj. Najveći udio u financiranju ublažavanja i usporavanja klimatskih promjena ima Svjetska banka.

Uloga razvojnih banaka u razvoju klimatskih financija kontinuirano se valorizira i unapređuje, a značajan napredak u transparentnosti i koordinaciji najznačajnijih razvojnih banaka učinjen je 2011. godine koja označava početak izrade zajedničkih godišnjih izvješća o uloženim klimatskim financijama. Koordinacija, zajednički nastup, izbjegavanje preklapanja financiranja, korištenje komparativnih prednosti svake od multilateralnih banaka veliki je doprinos budućnosti klimatskih financija. Naglasak je i na unapređenju i utvrđivanju efikasnosti klimatskih financija i postizanju ciljeva smanjenja emisije stakleničkih plinova te brže tranzicije ka nisko-ugljičnom gospodarstvu koje će biti otporno na klimatske promjene. $U$ tom smislu potrebno je izraditi zajednički sustav indikatora koji će na usporediv način moći svjedočiti o efikasnosti implementiranih klimatskih financija i o uspješnosti pojedinih razvojnih banaka u provođenju tranzicije ka zelenom rastu i zelenoj ekonomiji.

Ovaj rad je financiralo/sufinanciralo Sveučilište u Rijeci projektom uniri-drustv-18-61 i ZIP-UNIRI-130 5-20

\section{LITERATURA}

Abeille, V. et al. (2015) Estimating Private Climate Finance Mobilised by France's Climate Finance Interventions. Climate \& Energy Solutions/ARTELIA/Trinomics. http://www.oecd.org/env/researchcollaborative/Final\%20report-V5\%20 Artelia\%20Trinomics.pdf

Agrawala, S. et al. (2011) Private Sector Engagement in Adaptation to Climate Change: Approaches to Managing Climate Risks. OECD Environment Working Papers, No. 39., p. 19-44, https://www.cakex.org/sites/default/files/ documents $/ 5 \mathrm{~kg} 221 \mathrm{jkf1g7.pdf}$

Bartosch, S. et al. (2018) Aligning Investments with the Paris Agreement Temperature Goal: Challenges and Opportunities for Multilateral Development Banks. Germanwatch and NewClimate Institute Working Paper. https://germanwatch. org/en/15897

Broccolini, C. et al. (2020) Mobilization Effects of Multilateral Development Banks. Policy Research Working Paper, Series 9163. http://documents1.worldbank.org/curated/en/455301582642614413/pdf/Mobilization-Effects-ofMultilateral-Development-Banks.pdf 
Brown, J. et al. (2011) Improving the Effectiveness of Climate Finance: A Survey of Leveraging Methodologies. Overseas Development Institute, Climate Policy Initiative, Environmental Defense Club, Brookings, p. 4-19, http://www.edf. org/sites/default/files/effectiveness-\%20climate-finance-leveraging-methodologies.pdf

Brown, J. et al. (2015) Estimating Mobilized Private Finance for Adaptation: Exploring Data and Methods, Climate Policy Initiative and OECD, http://climatepolicyinitiative.org/wp-content/uploads/2015/11/Estimating-mobilizedprivate-finance-for-adaptation-Exploring-data-and-methods.pdf

Buchner, B., Brown, J., Corfee-Morlot, J. (2011) Monitoring and Tracking Long-Term Finance to Support Climate Action. OECD/IEA Climate Change Expert Group Papers, No. 2011(03), 5-62, https://www.oecd-ilibrary.org/ docserver/5k44zcqbbj42-en.pdf?expires=1597583164\&id=id\&accname=guest\&checksum=63B8B68062DC9131B BD384174CEA925D

Buchner, B. et al. (2012) The Landscape of Climate Finance 2012. Climate Policy Initiative, 5-80, https:// climatepolicyinitiative.org/wp-content/uploads/2012/12/The-Landscape-of-Climate-Finance-2012.pdf

Caruso, R., Ellis, J. (2013) Comparing Definitions and Methods to Estimate Mobilised Climate Finance. OECD/IEA Climate Change Expert Group Papers, No. 2013/02, p. 5-56. http://www.oecd.org/env/cc/ccxg.htm

Caruso, R., Jachnik, R. (2014) Exploring Potential Data Sources for Estimating Private Finance. OECD, Environment Working Papers, No. 69, p. 10-71, https://www.oecd-ilibrary.org/docserver/5jz15qwz4hs1-en.pdf?expires=15975833 83\&id=id\&accname=guest\&checksum=067D6CC7FBD82E64B48478A0E9816DFC

Culpeper, R. (2012) „Financial Sector Policy and Development in the Wake of the Global Crisis: The Role of National Development Banks", Third World Quarterly, 33 (3), p. 383-403. https://doi.org/10.1080/01436597.2012.657470.

De Luna-Martínez, J., Vicente, C. L. (2012) Global Survey of Development Banks. The World Bank, Policy Research Working Paper, No. 5969.

Ellis, J., Moarif, S. (2015) Identifying and addressing gaps in the UNFCCC reporting framework. OECD/IEA Climate Change Expert Group Papers, No. 2015(07), p. 5-37, https://www.oecd-ilibrary.org/docserver/5jm56w6f918n-en.pd f?expires $=1597583640 \&$ id=id\&accname $=$ guest $\&$ checksum $=469$ EB1F6F0488823C6FAB2FA3B0A4666

Eschalier, C., Cochran, I., Deheza, M. (2015) Climate and development finance institutions: linking climate finance, development finance and the transition to low-carbon, climate-resilient economic models. 114CE - Institute for Climate Economics. https://www.i4ce.org/wp-core/wp-content/uploads/2015/10/14CE-Mainstreaming-Climateand-LCCR-by-DFls-Paper-1_new.pdf

https://www.hbor.hr/arhiva-godisnjih-izvjesca/

IPCC (Intergovernmental Panel on Climate Change) (2014) Synthesis Report. Contribution of Working Groups I, II, and III to the Fifth Assessment Report of the Intergovernmental Panel on Climate Change. https://www.ipcc.ch/report/ ar5/syr/

Jachnik, R., Caruso, R., Srivastava, A. (2015) Estimating mobilised private climate finance: methodological approaches, options and trade-offs. OECD Environment Working Papers, No. 83, p. 1-66, https://www.oecd-ilibrary.org/ environment/estimating-mobilised-private-climate-finance_5js4x001rqf8-en

Jouanjean, M. A., Velde, D.W. (2013) The role of development finance institutions in promoting jobs and structural transformation: A quantitative Assessment. ODI Working Paper 377, https://www.odi.org/sites/odi.org.uk/files/odiassets/publications-opinion-files/8323.pdf

Kennedy, C., Corfee-Morlot, J. (2012) Mobilising Investment in Low Carbon, Climate Resilient Infrastructure. OECD Environment Working Papers, No. 46, https://www.oecd-ilibrary.org/docserver/5k8zm3gxxmnq-en.pdf?expires=15 97584489\&id=id\&accname $=$ guest $\&$ checksum $=397 D 7 F 02 A 3 B 7 C 453 F 47853872 A 3 D C 35 F$

Krstinić Nižić, M., Zubović, N. (2016) „Urbana ekologija kao temelj suvremenog življenja“, Zbornik Veleučilišta u Rijeci, 4(1), p. 45-58. Preuzeto s: https://hrcak.srce.hr/160233

Massa, I., Mendez-Parra, M., Te Velde, D. M. (2016) The macroeconomic effects of development finance institutions in sub-Saharan Africa. Overseas Development Institute, 5-52. https://www.odi.org/sites/odi.org.uk/files/resourcedocuments/11182.pdf 


\section{Draženović Kostelac, S. Benković, B. Olgić Draženović: Značaj razvojnih banaka za financiranje... Zbornik Veleučilišta u Rijeci, Vol. 9 (2021), No. 1, pp. 329-343}

Matić, B., Serdarušić, H. (2009) „Financing Regional Development Through Development Banks“ u Interdisciplinary Management Research. Osijek: Ekonomski fakultet u Osijeku; Hochschule Pforzheim University, p. 749-759.

McNicoll, L. et al. (2017). Estimating publicly-mobilised private finance for climate action: A South African case study. OECD Environment Working Papers, No. 125, p. 5-125. https://www.oecd-ilibrary.org/environment/estimatingpublicly-mobilised-private-finance-for-climate-action_a606277c-en

Miyamoto, K., Chiofalo, E. (2016) Official Development Finance for Infrastructure: With a Special Focus $n$ Multilateral Development Banks. OECD Development Co-operation Working Papers, No. 30, 5-24. https://www.cbd.int/ financial/doc/oecd-oda-infrastructure.pdf

Ockenden, S. et al. (2012) UK Working Paper: A project level approach to forecast and monitor private climate finance mobilized, http://www.oecd.org/env/cc/2012_UK_Approach_paper.pdf

OECD (2018) Mobilising commercial capital for sustainable infrastructure: Insights from national development banks in Brazil and South Africa (forthcoming). Financing Climate Futures Case Studies, OECD Publishing, Paris.

OECD (2019) Climate Related Development Finance Data, 3. http://www.oecd.org/dac/financing-sustainabledevelopment/development-finance-topics/climate-change.htm

Pauw, W. P. et al. (2015) „Private finance for adaptation: do private realities meet public ambitions?", Climatic Change, 134, p. 489-503, https://doi.org/10.1007/s10584-015-1539-3.

Srivastava, A., Venugopal, S. (2014) Evaluating Methods to Estimate Private Climate Finance Mobilized from Public Interventions. World Resources Institute Research Collaborative on Tracking Private Climate Finance: Part B, Work stream 2, p. 5-143. http://www.oecd.org/env/researchcollaborative/WRI_WS2_Part_B.pdf

Stadelmann, M., Michaelowa, A. (2013) Contribution of the private sector to Climate Change Long-Term-Finance: assessment of private climate finance mobilized by Switzerland. Final report for the Swiss Federal Office for the Environment, p. 5-41, https://www.researchgate.net/publication/282195652_Contribution_of_the_private_ sector_to_Climate_Change_Long-Term-Finance_An_assessment_of_private_climate_finance_mobilized_by_ Switzerland

Stumhofer, T. et al. (2015) Proposal of a methodology for tracking publicly mobilized private climate finance. KfW Development Bank Materials on Development Financing No 9, p. 1-29, https://www.kfw-entwicklungsbank.de/ PDF/Download-Center/Materialien/Nr-9_Proposal-of-a-methodology-for-tracking-publicly-mobilized-privateclimate-finance.pdf

Šverko Grdić, Z. , Špoljarić, T. (2018) „Utjecaj klimatskih promjena na turističke tijekove - primjer Republike Hrvatske“, Zbornik Veleučilišta u Rijeci, 6 (1), p. 51-66. https://doi.org/10.31784/zvr.6.1.1

Te Velde, D.W. (2011) The role of development finance institutions in tackling global challenges. Overseas Development Institute, p. 7-33, https://www.odi.org/sites/odi.org.uk/files/odi-assets/publications-opinion-files/7310.pdf

Thorne, J., du Toit, C. (2009) „A Macro-Framework for Successful Development Banks“. Development Southern Africa, 26(5), p. 677-694: https://doi.org/10.1080/03768350903303183.

Tirpak, D., Brown, L., Ronquillo-Ballesteros, A. (2014) Monitoring Climate Finance in Developing Countries: Challenges and Next Steps. World Resources Institute Working Paper, https://files.wri.org/s3fs-public/wri13_monitoringclimate_ final_web.pdf

UNEP (2016) The Adaptation Finance Gap Report (2016) United Nations Environment Programme (UNEP), Nairobi, https://climateanalytics.org/media/agr2016.pdf

UNFCCC (2015) Climate Finance: Sources of Funding and Instruments. Inter-American Development Bank Infrastructure and Environment Sector Climate Change and Sustainability Division, https://unfccc.int/files/gender_and_ climate_change/application/pdf/a1_moderator_amin.pdf

Whitley, S., Ellis, K. (2012) Designing public sector interventions to mobilise private participation in low carbon development: 20 questions toolkit. Overseas Development Institute, Working Paper 346, https://www.odi.org/sites/ odi.org.uk/files/odi-assets/publications-opinion-files/7660.pdf

Würtenberger, L., Wils, F. (2014) Tackling Climate Change at Scale: Mobilising private sector investments through technical assistance - GIZ's experiences and lessons learned. 


\title{
THE IMPORTANCE OF DEVELOPMENT BANKS FOR FINANCING CLIMATE CHANGE MITIGATION AND ADAPTATION
}

\section{Draženka Draženović Kostelac}

MSc, Head of the regional office, Croatian Bank for Reconstruction and Development, Strossmayerov trg 9, 10000 Zagreb, Croatia; e-mail: ddrazenovic@hbor.hr

\section{Slađana Benković}

PhD, Full Professor, University of Belgrade, Faculty of Organizational Sciences, Jove llića 154, 11000 Belgrade, Serbia; e-mail: sladjana.benkovic@fon.bg.ac.rs

\section{Bojana Olgić Draženović}

PhD, Associate Professor, University of Rijeka, Faculty of Economics and Business, I. Filipovića 4, 51000 Rijeka, Croatia; e-mail: bojana.olgic.drazenovic@efri.hr

\begin{abstract}
Climate change and global negative consequences require measures to adapt to a more sustainable model of economic growth and development. Therefore, mitigating the harmful effects and promoting a sustainable and climate-resilient economy is a priority. One of the key roles in the process of transforming economies into a low-carbon future is played by development banks. The aim of this paper is to investigate the role of development banks in climate finance through a review of the literature and analysis of data on climate finance of member states of the Development Assistance Committee within the Organization for Economic Cooperation and Development in 2012-2018. A methodological approach to the analysis of existing theoretical starting points and empirical analysis of available secondary data was used. The expected contribution of this paper is to increase the visibility of the importance of development banks as channels for the distribution of climate finance, which were significant stakeholders in the transmission of climate finance from developed to less developed countries.
\end{abstract}

Key words: climate finance, development banks, sustainable development 
